\title{
Spider (Araneae) Species Composition and Seasonal Abundance in San Joaquin Valley Grape Vineyards
}

\author{
MICHAEL J. COSTELLO ${ }^{1}$ AND KENT M. DAANE
}

Laboratory of Biological Control, University of California, Berkeley, Keamey Agricultural Center, Parlier, CA 93648

\begin{abstract}
Environ. Entomol. 24(4): 823-831 (1995)
ABSTRACT As part of an investigation to estimate the effect of resident spider populations on Erythroneura variabilis Beamer, spider species composition, relative abundance, and seasonal occurrence were determined. Spiders were sampled monthly during the 1992 and 1993 growing seasons; their numbers were pooled and analyzed for species diversity using the Renkonen index of similarity and cluster analysis. Twenty-seven species of spiders were recorded, representing 14 families. The most common species were Cheiracanthium inclusum (Hentz), Trachelas pacificus (Chamberlin and Ivie), Theridion dilutum Levi, Theridion melanurum Hahn, Oxyopes scalaris Hentz, Oxyopes salticus Hentz, Hololena nedra Chamberlin and Ivie, and Metaphidippus vitis (Cockerell). Three species (C. inclusum, $T$. dilutum, and $T$. melanurum) constituted $>30 \%$ of all spiders collected; however, species diversity varied among vineyard sites. In 4 vineyard sites, hunting spiders (C. inclusum, $T$. pacificus, Oxyopes spp., and $M$. vitis) dominated the fauna, representing an average of $79.7 \%$ of the specimens collected. In the other 3 vineyards, hunting and web-weaving spiders were more equally represented, averaging 43.5 and $50.0 \%$, respectively, of all spiders collected. Species similarity between vineyards from both years ranged from 19 to $73 \%$ based on the Renkonen index. Similarly, cluster analysis showed a wide separation in species composition among sampled vineyards. The discrepancy in species similarity among sampled vineyards is discussed in reference to potential prey density and vineyard cultural practices. Seasonal abundance patterns of the 8 most common species are presented and discussed in reference to their respective phenologies.
\end{abstract}

KEY WORDS Araneae, Theridion, Cheiracanthium, Erythroneura variabilis, species diversity, vineyards

SPIDERS ARE A major component of predator communities in many agroecosystems (Roach 1980; Ferguson et al. 1984; Nyffeler and Benz 1987; Knutson and Gilstrap 1989; Breene et al. 1989, 1993; Nyffeler et al. 1994). Nevertheless, spider species composition and relative abundance is poorly understood in most cropping systems, as is the role they play in the regulation of crop pests (Agnew and Smith 1989). In part, the underrepresentation of spiders in the agricultural literature is because of certain biological characteristics that make laboratory and field studies difficult. In the laboratory, the cannibalistic behavior of some species necessitates separate rearing containers, and their slow development makes studies of spider biology time consuming and expensive. In the field, many spider species have cryptic behaviors, such as nocturnal foraging habits, which hamper sampling and behavioral studies. Spiders are often difficult to identify because most specimens collected are juveniles, whereas identification keys are for adults, and there are few taxonomists trained in arachnology compared with those trained in ento-

${ }^{1}$ Current address: University of California Cooperative Extension, 1720 South Maple, Fresno, CA, 93702. mology. Spiders have been often considered less than ideal biological control agents (Riechert and Lockley 1984) partly because they have long generation times relative to pest species, and, therefore, individual species have not been observed to exhibit a timely numerical response to changes in pest densities.

Recent interest in spiders as biological control agents of pests in California table, raisin, and wine grape vineyards has encouraged efforts to understand the role of resident spider species. In the San Joaquin Valley, it has been suggested that spiders play a significant role in the natural regulation of the Erythroneura variabilis Beamer (Homoptera: Cicadellidae) (Wilson et al. 1992), the primary insect pest in this important California grape region (Settle et al. 1986). However, there is relatively little information about the spider fauna in grape agroecosystems, even though spiders have been noted as abundant predators in vineyards (Cate 1975). Roltsch et al. (1995) discussed sampling methods and included a partial list of spider species collected from San Joaquin Valley vineyards, and Kirn (1978) studied the spider community of the vineyard floor in Germany. The current stıdy 


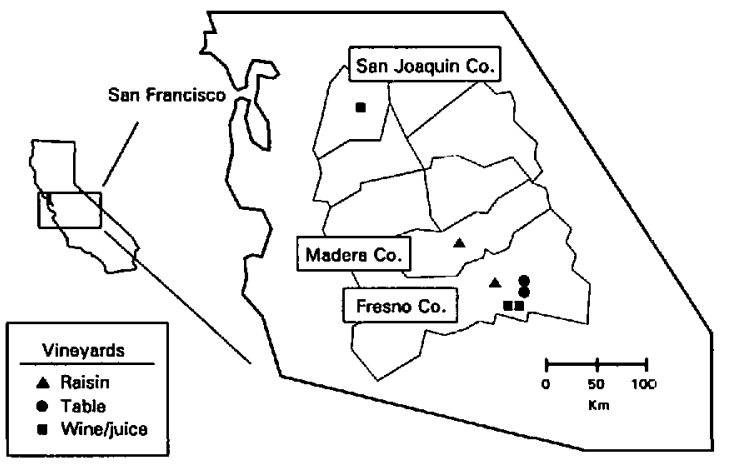

Fig. 1. Location of 7 grape vineyards sampled in 1992 (Fresno and Madera counties) and 1993 (Fresno and San Joaquin counties).

was undertaken as part of an effort to improve understanding of the effect of resident spider populations on $E$. variabilis. The results from $2 \mathrm{yr}$ of spider sampling are presented, with a discussion of species composition and diversity among sites and the seasonal abundance of the more common species.

\section{Materials and Methods}

We sampled 5 commercial and 2 experimental vineyards in the San Joaquin Valley in 1992 and 1993 (Fig. 1). The 7 vineyard sites included different grape cultivars and vineyard cultural practices and are subsequently referred to as WINE, RAISIN, or TABLE to underscore the differences. Important differences between vineyards were location, market (raisin, table, or wine), trellis system, and floor management (Table 1). Factors that can affect the spider fauna include age of the vineyard, abundance of prey, use of pesticides, and cultural practices that change the vineyard microclimate, such as trellis system, irrigation, or the presence of ground covers.

The most abundant potential prey throughout the grape-growing season was $E$. variabilis. Also present was the western grape leafhopper, Ery- throneura elegantula Osborn, but at much lower densities. Estimations of leafhopper population densities were made by counting $E$. variabilis and E. elegantula nymphs on 40 leaves per vineyard at periods of peak nymphal densities for each of the 3 leafhopper broods; counts were made using procedures described by Wilson et al. (1992). Insect pest control tactics varied only slightly among the vineyards, and no pest management practices were used that were likely to affect either leafhopper or spider numbers directly. Each vineyard received applications of sulfur for control of powdery mildew, Uncinula necator Burrill, (WINE3 applied a sterol inhibitor after mid-June), and cryolite (TABLE1, TABLE2, RAISIN1, and RAISIN2), Cryocide (WINE1 and WINE2), or a formulation of Bacillus thuringiensis Berliner (TABI,E1 and RAISIN1) for control of 2 lepidopteran pests-western grapeleaf skeletonizer, Harrisina brillians Barns and McDunnough, and Platynota stultana Walshingham.

In each vineyard, spider samples were taken monthly, from July to September 1992, and from May to September 1993. To sample, a drop cloth ( 3 by $5 \mathrm{~m}$ ) was laid on the ground underneath the vine canopy, covering an area below 2 grape vines. The vines were vigorously shaken for $\approx 30 \mathrm{~s}$ and the trunks and trellis wires were struck with a mallet to dislodge spiders onto the drop cloth below. The spiders were then collected with small batterypowered vacuums (Dustbuster, Black and Decker, Towson, MD) that had the cloth filter inside replaced with an organdy screen to collect live spiders. The collection procedure was repeated, and the total number of spiders collected from the two shakings constituted the sample. Spiders were transferred in the field to plastic bags and placed in ice chests to retard spider metabolism, which minimized predation during transport. In each vineyard and on each sampling date, samples were taken between 0700 and 1200 hours and again between 1900 and 2400 hours, with the exception of the WINE3 site, at which only morning samples were taken (1992: TABLEl $[n=45]$, WINEl [ $n$

Table 1. Characteristics of the 7 grape vineyards surveyed for spiders

\begin{tabular}{|c|c|c|c|c|c|c|c|}
\hline Site & Town, county & Market & Cultivar & $\begin{array}{l}\text { Size, } \\
\text { ha }\end{array}$ & Trellis system & Cover crops & Year \\
\hline TABLE1 & Reedley, Fresno & Table grape & Thompson Seedless & 16 & 4-Wire, $1.4 \mathrm{~m} \mathrm{~T}$ & Year round & 1992 \\
\hline TABLE2 & Reedley, Fresno & Table grape & Ruby Seedless & 8 & 2-Wire, $1.4 \mathrm{~m} \mathrm{~T}$ & Year round & 1993 \\
\hline RAISIN1 & Del Rey, Fresno & Raisin grape & Thompson Seedless & 9 & 1-Wire & $\begin{array}{l}\text { Winter weeds } \\
\text { summer clean } \\
\text { cultivated }\end{array}$ & 1992,1993 \\
\hline RAISIN2 & Madera, Madera & Raisin grape & Thompson Seedless & 16 & 1-Wire & $\begin{array}{l}\text { Winter cover } \\
\text { crop/summer } \\
\text { clean cultivat- } \\
\text { ed }\end{array}$ & 1992 \\
\hline WINEl & Parlier, Fresno & Wine/juice & Thompson Seedless & 0.5 & 2-Wire, $0.5 \mathrm{~T}$ & Year round & 1992,1993 \\
\hline WINE2 & Parlier, Fresno & Wine/juice & Thompson Seedless & 0.7 & 2-Wire, $0.5 \mathrm{~T}$ & Year round & 1993 \\
\hline WINE3 & $\begin{array}{l}\text { Woodbridge, San } \\
\text { Joaquin }\end{array}$ & Wine & Cabernet Suuvignon & $\mathrm{g}$ & $\begin{array}{l}\text { 4-Wire, } 1.0 \text { m bi- } \\
\text { lateral } \mathrm{T}\end{array}$ & $\begin{array}{l}\text { Winter weeds/ } \\
\text { summer clean } \\
\text { cultivated }\end{array}$ & 1993 \\
\hline
\end{tabular}


$=45$ ], RAISIN1 [ $n=30$ ] and RAISIN2 [ $n=30]$ ); 1993: TABLE2 [ $n=50]$, WINE1 $[n=40]$, WINE2 $[n=72]$, WINE3 $[n=50]$, and RAISINI $[n=32]$ ). In the laboratory, samples were cleaned of plant debris and all specimens were placed in a $70 \%$ ethanol solution and sorted by taxon.

For all analyses, day and night spider samples were pooled for each sample date and vineyard. For species diversity analyses, data from both years were pooled. Spider species diversity among vineyards was estimated using the Renkonen index of similarity (Krebs 1989) and by cluster analysis using the average linkage method (unweighted pair group method using arithmetic averages, [UPGMA], PROC CLUS, SAS Institute 1992). Because we were most interested in how changes in spider species composition affected pest populations, especially leafhoppers, we restricted the spider species diversity analyses to those species collected frequently enough to be considered as having an impact on pest populations. These were Cheiracanthium inclusum (Hentz), Trachelas pacificus (Chamberlin and Ivie), Theridion dilutum Levi, Theridion melanurum Hahn, Oxyopes scalaris Hentz, Oxyopes salticus Hentz, Hololena nedra Chamberlin and Ivie, and Metaphidippus vitis (Cockerell). Adult and juvenile spider densities in 1993 are presented by degrees-days $\left(>10^{\circ} \mathrm{C}\right.$, starting 1 January 1993), using the single sine method. Temperatures at each location were taken from University of California Division of Natural Resources IMPACT (Integrated Management of Production in Agriculture Using Computer Technology) weather stations. To test for a relationship between leafhopper density and spider species composition, the proportion of each spider in each vineyard was regressed against mean cumulative leafhopper density (combination of $E$. variabilis and E. elegantula).

\section{Results and Discussion}

Species Composition and Diversity Indices. More than 11,000 spiders were collected, from which 27 species were recorded, representing 14 families (Table 2). In all but 1 vineyard, 8 species constituted $>80 \%$ or more of the specimens collected. These species were $C$. inclusum, $T$. pacificus, T. dilutum, T. melanurum, $O$. scalaris and $O$. salticus (grouped as Oxyopes spp. because we could not distinguish them from each other as juveniles), $H$. nedra, and $M$. vitis. The 1 vineyard that provided the exception was WINE2, which was dominated by Anyphaena pacifica Banks (62.4 and $30.4 \%$ of all spiders collected in 1992 and 1993, respectively). Our findings are similar to those of Roltsch et al. (1995), who sampled 11 central California vineyards monthly and found that C. inclusum, T. pacificus, $H$. nedra, 2 Theridion spp. (presumably T. dilutum and T. melanurum), 2 oxyopid spp. (presumably $O$. scalaris and $O$. salti- cus), and 4 salticid spp. (M. vitis is not mentioned) constituted the majority of spiders collected.

The dominance of the spider fauna in agroecosystems by a relatively small proportion of the species present has been reported by other researchers. Three out of 41 species collected made up from 50 to $76 \%$ of the spider community in a Quebec apple orchard (Dondale et al. 1979) and 7 out of 97 species collected made up half of the spiders found in East Texas cotton (Dean et al. 1982). In the present study, 3 species (C. inclusum, T. dilutum, and T. melanurum) constituted $>30 \%$ of all spiders collected, and, in 3 vineyards sampled, $C$. inclusum and Theridion spp. constituted $>60 \%$ of the specimens collected (Table 1). Cheiracanthitum and Theridion have made up a high proportion of the spider fauna in other agroecosystems as well. Bishop (1980) found that Cheiracanthium diversum L. Koch and a Theridion sp. made up between 49.6 and $67 \%$ of the spider fauna on cotton in Australia. Mansour and Whitcomb (1986) found that Cheiracanthium mildei L. Koch and a Theridion sp. constituted $86 \%$ of the foliage-dwelling spiders in a citrus grove in Israel.

The species that had the most even distribution was C. inclusum (Table 2). This spider, which was represented at all sites in both years, made up an average of $22.4 \%$ of the spiders collected and did not show an abundance pattern that corresponded to vineyard condition, cultural practice, or leafhopper density. This suggests that C. inclusum has the most plastic genome and is competitive under a wider range of conditions and prey types than the other spider species collected. At: WINE1, where C. inclusum was most poorly represented (5.0 and $13.5 \%$ of the spider fauna in 1992 and 1993, respectively), we suspect that $C$. inclusum was competitively displaced by $A$. pacifica, which, as a nocturnal, hunting spider, may be an ecological homolog of C. inclusum. In contrast to C. inclusum, the Theridion spp. abundance varied greatly among vineyards, constituting $>40 \%$ of the collected specimens in some vineyards (RAISIN1 and RAISIN2 in 1992, RAISIN1 and WINE3 in 1993) and $<1 \%$ in others (WINE1 in 1992, TABLE2 in 1993).

One discrepancy between the apparent and actual abundance of spiders is Neoscona oaxacensis (Keyserling). Although it is one of the most visible spiders because of its habit of building its web between rows of vines, it did not constitute a high percentage of spiders collected. We believe this is caused in part by sampling method, as more specimens of $N$. oaxacensis were collected in the spring and early summer of 1993, when $N$. oaxacensis is a small $(1-5 \mathrm{~mm})$ spiderling and is more easily dislodged. As the season progressed and $N$. oaxacensis increased in size, it became more difficult to shake loose, which was reflected by a reduction in the numbers collected. Thus, $N$. oaxacensis was not collected in 1992, the year that sampling did not begin until July. 
Table 2. Spider species found in San Joaquin Valley vineyards, listed by percent collected within each site and year

\begin{tabular}{|c|c|c|c|c|c|c|c|c|c|}
\hline \multirow{3}{*}{ Spider } & \multicolumn{9}{|c|}{ Species abundance per vineyard, $\%$} \\
\hline & \multicolumn{4}{|c|}{1992} & \multicolumn{5}{|c|}{1993} \\
\hline & TABLEl & $\begin{array}{l}\text { RAI- } \\
\text { SIN2 }\end{array}$ & $\begin{array}{l}\text { RAI- } \\
\text { SIN1 }\end{array}$ & WINEI & TABLE2 & $\begin{array}{l}\text { RAI- } \\
\text { SIN1 }\end{array}$ & WINEI & WINE2 & WINE3 \\
\hline \multicolumn{10}{|l|}{ Agelenidae } \\
\hline Hololena nedra Chamberlin \& Ivie & 5.9 & 7.2 & 7.5 & 4.7 & 3.5 & 11.8 & 13.8 & 7.9 & $<1.0$ \\
\hline \multicolumn{10}{|l|}{ Anyphaenidae } \\
\hline $\begin{array}{l}\text { Anyphaena pacifica Banks } \\
\text { Aysha incursa (Chamberlin) }\end{array}$ & $\begin{array}{r}0 \\
<1.0\end{array}$ & $\begin{array}{r}<1.0 \\
0\end{array}$ & $\begin{array}{r}<1.0 \\
0\end{array}$ & $\begin{array}{r}62.4 \\
0\end{array}$ & $\begin{array}{l}<1.0 \\
<1.0\end{array}$ & $\begin{array}{r}<1.0 \\
0\end{array}$ & $\begin{array}{r}30.4 \\
0\end{array}$ & $\begin{array}{l}<1.0 \\
<1.0\end{array}$ & $\begin{array}{l}0 \\
0\end{array}$ \\
\hline \multicolumn{10}{|l|}{ Araneidae } \\
\hline Neoscona oaxacensis (Keyserling) & 0 & 0 & 0 & 0 & 5.2 & $<1.0$ & $<1.0$ & 4.4 & $<1.0$ \\
\hline \multicolumn{10}{|l|}{ Clubionidae } \\
\hline $\begin{array}{l}\text { Cheiracanthium inclusum (Hentz) } \\
\text { Trachelas pacificus (Chamberlin \& Ivie) }\end{array}$ & $\begin{array}{l}27.9 \\
40.2\end{array}$ & $\begin{array}{l}19.7 \\
11.2\end{array}$ & $\begin{array}{l}28.5 \\
16.2\end{array}$ & $\begin{array}{l}5.5 \\
5.9\end{array}$ & $\begin{array}{r}8.7 \\
48.0\end{array}$ & $\begin{array}{l}17.0 \\
17.8\end{array}$ & $\begin{array}{l}13.0 \\
16.1\end{array}$ & $\begin{array}{r}44.5 \\
7.2\end{array}$ & $\begin{array}{r}37.3 \\
<1.0\end{array}$ \\
\hline \multicolumn{10}{|l|}{ Dictynidae } \\
\hline Dictyna calcarata (Banks) & 0 & $<1.0$ & 0 & $<1.0$ & 0 & $<1.0$ & 0 & 0 & 0 \\
\hline \multicolumn{10}{|l|}{ Gnaphosidae } \\
\hline Nodocion voluntarius (Chamberlin) & $<1.0$ & $<1.0$ & 0 & $<1.0$ & $<1.0$ & $<1.0$ & $<1.0$ & $<1.0$ & $<1.0$ \\
\hline $\begin{array}{l}\text { Linyphiidae } \\
\text { Erigone dentosa (O. P.-Cambridge })^{a}\end{array}$ & 0 & 0 & 0 & 0 & $<1.0$ & 3.2 & 1.6 & 1.0 & 3.3 \\
\hline \multicolumn{10}{|l|}{ Lycosidae } \\
\hline $\begin{array}{l}\text { Pardosa ramulosa (McCook) } \\
\text { Schizocosa mccooki (Montgomery) }\end{array}$ & $\begin{array}{l}0 \\
0\end{array}$ & $\begin{array}{r}0 \\
<1.0\end{array}$ & $\begin{array}{l}0 \\
0\end{array}$ & $\begin{array}{r}0 \\
<1.0\end{array}$ & $\begin{array}{l}<1.0 \\
<1.0\end{array}$ & $\begin{array}{r}<1.0 \\
0\end{array}$ & $\begin{array}{l}<1.0 \\
<1.0\end{array}$ & $\begin{array}{r}<1.0 \\
0\end{array}$ & $\begin{array}{r}<1.0 \\
0\end{array}$ \\
\hline \multicolumn{10}{|l|}{ Mimetidae } \\
\hline Mimetus hesperus (Chanberlin) & 0 & $<1.0$ & $<1.0$ & $<1.0$ & $<1.0$ & $<1.0$ & $<1.0$ & $<1.0$ & $<1.0$ \\
\hline \multicolumn{10}{|l|}{ Oxyopidae } \\
\hline Oxyopes scalaris, $O$ salticus ${ }^{b}$ & 11.5 & 15.2 & $<1.0$ & 1.4 & 8.2 & 2.3 & 1.9 & 2.1 & 5.5 \\
\hline \multicolumn{10}{|l|}{ Philodromidae } \\
\hline Tibellus chamberlini Gertsch & 0 & 0 & 0 & 0 & 0 & 0 & $<1.0$ & 0 & 0 \\
\hline \multicolumn{10}{|l|}{ Salticidae } \\
\hline $\begin{array}{l}\text { Metaphidippus vitis (Cockerell) } \\
\text { Platycryptus californicus (Peckham \& Peck- } \\
\text { ham) }\end{array}$ & 2.8 & $<1.0$ & $<1.0$ & 5.2 & 18.2 & 1.3 & 14.0 & 23.6 & 0 \\
\hline $\begin{array}{l}\text { ham) } \\
\text { Phidippus johnsoni (Peckham \& Peckham) }\end{array}$ & $\begin{array}{r}0 \\
<1.0\end{array}$ & $<1.0$ & $\begin{array}{l}0 \\
0\end{array}$ & $\begin{array}{l}<1.0 \\
<1.0\end{array}$ & $\begin{array}{l}<1.0 \\
<1.0\end{array}$ & $\begin{array}{r}0 \\
<1.0\end{array}$ & $\begin{array}{r}0 \\
<1.0\end{array}$ & $\begin{array}{r}2.2 \\
<1.0\end{array}$ & $\begin{array}{l}0 \\
0\end{array}$ \\
\hline Phidippus clarus Keyserling & $<1.0$ & 0 & 0 & $<1.0$ & $<1.0$ & 0 & $<1.0$ & $<1.0$ & $<1.0$ \\
\hline Thiodina sp. nov. & 0 & 0 & 0 & 0 & $<1.0$ & 0 & 0 & $<1.0$ & $<1.0$ \\
\hline Metacyrba taeniola (Hentz) & 0 & 0 & 0 & $<1.0$ & $<1.0$ & $<1.0$ & $<1.0$ & $<1.0$ & 0 \\
\hline \multicolumn{10}{|l|}{ Theridiidae } \\
\hline $\begin{array}{l}\text { Theridion spp.c } \\
\text { Theridion dilutum Levi } \\
\text { Theridion melanurum Hahn } \\
\text { Latrodectus hesperus Chamberlin \& Ivie }\end{array}$ & 7.8 & 42.1 & 44.3 & $<1.0$ & $\begin{array}{r}<1.0 \\
<1.0 \\
0\end{array}$ & $\begin{array}{r}7.4 \\
32.9 \\
<1.0\end{array}$ & $\begin{array}{r}1.4 \\
5.6 \\
<1.0\end{array}$ & $\begin{array}{r}2.4 \\
<1.0 \\
<1.0\end{array}$ & $\begin{array}{l}10.8 \\
29.5 \\
<1.0\end{array}$ \\
\hline \multicolumn{10}{|l|}{ Thomisidae $^{d}$} \\
\hline$X$. loculipes, $C$. utahensis, Misumenops sp. & 0 & $<1.0$ & 0 & $<1.0$ & $<1.0$ & 2.2 & 0 & $<1.0$ & 3.9 \\
\hline Unidentified spiders & 3.8 & 3.9 & 2.3 & 5.5 & 6.6 & 3.3 & 1.4 & 6.0 & 5.6 \\
\hline $\begin{array}{l}\text { Total spiders collected } \\
\text { Average spiders/sample }\end{array}$ & $\begin{array}{l}1,513 \\
33.6\end{array}$ & $\begin{array}{c}775 \\
25.8\end{array}$ & $\begin{array}{l}797 \\
26.5\end{array}$ & $\begin{array}{r}1,869 \\
41.5\end{array}$ & $\begin{array}{c}1,110 \\
22,2\end{array}$ & $\begin{array}{l}2,153 \\
67.2\end{array}$ & $\begin{array}{l}784 \\
19.6\end{array}$ & $\begin{array}{r}1,396 \\
1.9 .3\end{array}$ & $\begin{array}{c}1,184 \\
23.7\end{array}$ \\
\hline
\end{tabular}

${ }^{a}$ Samples were not taken in spring and early summer, when $N$. oaxacensis is more easily collected and $E$. dentosa is present.

${ }^{b}$ Oxyopes scalaris Hentz and Oxyopes salticus Hentz were not separated by species in the samples.

c Theridion dilutum and T. melanurum were not separated by species in the 1992 samples.

${ }^{d}$ The Thomisidae spp. Xysticus loculipes Keyserling, Coriurache utahensis (Gertsch), and Misumenops sp. were not separated by species in the samples.

Species similarity between vineyards from both years ranged from 19 to $73 \%$ based on the Renkonen index (Table 3). Given the wide range of vineyard conditions and grower cultural practices among the study vineyards and that 2 different years are involved, one would expect some species variability. However, this is a much wider range than found by LeSar and Unsicker (1978), who used the quotient of similarity (Southwood 1978) and found a range of $0.64-0.79$ (on a scale of $0-$ 
Table 3. Renkonen indices of similarity (percent similarity) for comparisons of spider species composition between sampled vineyards

\begin{tabular}{|c|c|c|c|c|c|c|c|}
\hline & TABLE1 & TABLE2 & RAISIN1 & RAISIN2 & WINE1 & WINE? & WINE3 \\
\hline $\begin{array}{l}\text { TABLEI } \\
\text { TABLE2 } \\
\text { RAISIN1 } \\
\text { RAISIN2 } \\
\text { WINE1 } \\
\text { WINE2 } \\
\text { WINE3 }\end{array}$ & $\begin{array}{l}-\overline{0.66} \\
0.58 \\
0.54 \\
0.42 \\
0.51 \\
0.40\end{array}$ & $\begin{array}{l}\overline{0.35} \\
0.34 \\
0.33 \\
0.54 \\
0.20\end{array}$ & $\begin{array}{l}\overline{0.62} \\
0.41 \\
0.44 \\
0.73\end{array}$ & $\begin{array}{l}-\overline{0.39} \\
0.34 \\
0.45\end{array}$ & $\begin{array}{l}-\overline{0.38} \\
0.19\end{array}$ & $\widetilde{0.56}$ & - \\
\hline
\end{tabular}

Index is based on the 8 most common spider species.

1) in 1 yr among 3 soybean field sites. WINE1 had the least amount of similarity overall to all other sites $(<43 \%)$ because of the dominance of $A$. pacifica. RAISIN1 and WINE3 had the highest similarity (73\%).

Cluster analysis revealed a similar pattern of species diversity among the sites (Fig. 2). As was seen with the Renkonen index, the highest similarity was between WINE3 and RAISIN1 (CL [cluster] 6), which clustered first (average distance 0.57), whereas WINE2 and TABLE2, which had only a moderate Renkonen similarity, clustered independently and at a slightly greater distance at 0.62 (CL 5). With the addition of RAISIN2 to CL 6 and TABLE1 to CL 5, two distinct clusters are evident: the 1st consisting of WINE2, TABLE2, and TABLE1 (CL Fig. 2) the other of WINE3, RAISIN1, and RAISIN2 (CL 3) (Fig. 2). However, the clustering procedure did not reveal which of the spider species explained the greatest amount of the variability among vineyards.

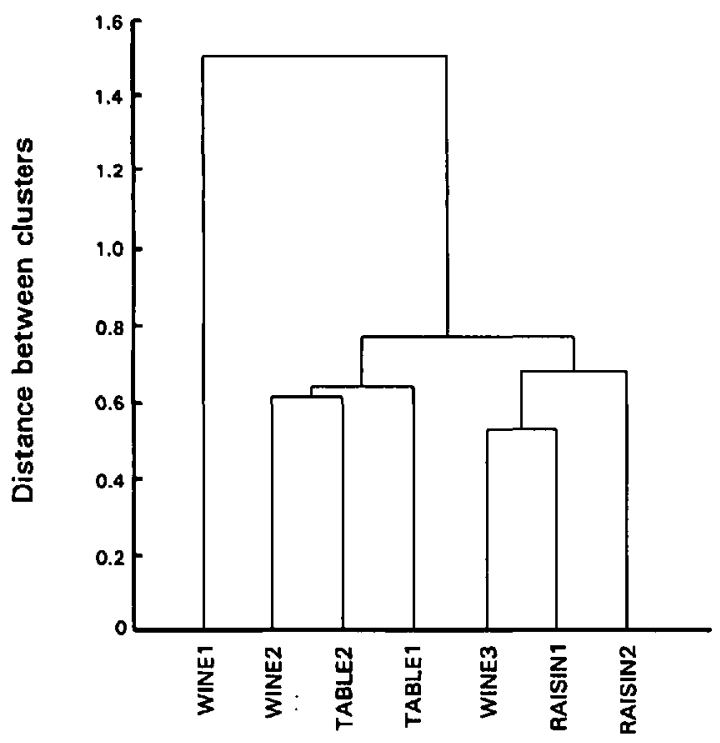

Vineyard

Fig. 2. Dendogram of spider species diversity based on average linkage cluster analysis. The analysis includes all sites across both sampling years.
Spider faunae are sometimes classified according to method of prey capture (Agnew and Smith 1989). To evaluate species diversity, we grouped those spiders that constituted $>1 \%$ of the population at the sampled vineyards into groups based on their predatory habits, as follows: hunters, $C$. inclusum, T. pacificus, O. scalaris, $M$. vitis, and Platycryptus califormicus (Peckham and Peckham), and sit-and-wait web builders, $T$, dilutum, $T$. $m e$ lanurum, $H$. nedra, $N$. oaxacensis, and Erigone dentosa (O.P.-Cambridge). C. inclusum, T. pacificus, and $A$. pacifica are nocturnal hunting spiders that locate their prey by tarsal contact, whereas $O$. scalaris, $M$. vitis, and $P$. californicus are diurnal, highly visually oriented, and can jump many times their body length to pounce on their prey. Of the webweavers, T. dilutum and T. melanurum construct their fine, irregular network of webbing, typically on the underside of the grape leaf, often at the point where the petiole attaches to the leaf blade. $H$. nedra, one of the most visible spiders we collected constructs its funnel-shaped web on the upper side of the grape leaf; by season end, a substantial proportion of the foliage can be covered with web. Although Gertsch (1979) classified funnelweavers (Agelinidae) as hunters, probably because of the speed and agility with which they move, it seems more appropriate to group them as sit-and-wait predators. $N$. oaxacensis constructs its orb web in different locations depending on developmental stage; small, immature $N$. oaxacensis spin webs on the grape foliage or trellis wire, but as this species matures, it strings its web between grapevine rows. At TABLE1, TABLE2, WINE1, and WINE2, the hunting spiders dominated the fauna, representing an average of $79.7 \%$ and webspinners an average of $14.8 \%$ of all spiders collected. At RAISIN1, RAISIN2, and WINE3, hunters and webspinners were more equally represented, averaging 43.5 and $50.0 \%$, respectively, of all spiders collected. The Thomisidae (crab spiders) do not fit neatly into either predatory group. Although most are considered sit-and-wait predators (Nyffeler et al. 1994), they have also been found to actively forage (McDaniel and Sterling 1982). We did not observe the predatory behavior of the thomisids we collected, Xysticus loculipes Keyserling, Coriarache utahensis (Gertsch), and Misu- 
Table 4. Test statistics and associuted probabilities for single variable regression of leafhopper, E. variabilis and E. elegantula, and spider densities

\begin{tabular}{|c|c|c|c|c|c|}
\hline $\begin{array}{l}\text { Mean density } \\
\text { per sarmple }\end{array}$ & Intercept & Slope & $r^{2}$ & $F$ & $P$ \\
\hline All spider species & 19.56 & 0.84 & 0.023 & 1.166 & 0.322 \\
\hline Cheiracanthium inclusum & 3.87 & 0.24 & 0.104 & 1.814 & 0.227 \\
\hline Trachelas pacificass & 1.80 & 0.32 & 0.044 & 1.325 & 0.294 \\
\hline Theridion spp. & -5.14 & 1.02 & 0.516 & 8.472 & 0.027 \\
\hline Oxyopes spp. & 1.21 & 0.04 & 0.001 & 0.266 & 0.624 \\
\hline Hololena nedra & 0.32 & 0.15 & 0.053 & 1.395 & 0.282 \\
\hline Metaphidippus vitis & 4.10 & -0.20 & 0.499 & 7.975 & 0.030 \\
\hline
\end{tabular}

Dependent variable in each case is mean leafhopper density per leaf; data not available for WINEl; therefore, in each case, df = $1,6$.

menops sp., and their combined numbers were never $>4 \%$ of the spider community at any site (Table 2).

The Renkonen index, cluster analysis, and classification according to predatory habits of common spiders all indicate a similar grouping of vineyards with respect to spider species diversity. The pattern that emerges separates vineyards into 2 distinct groups with TABLE1, TABLE2, WINE1, and WINE2 as the 1st group and RAISIN1, RAISIN2, and WINE3 as the 2nd. The unifying factor for each of these groups is vineyard floor management: summer ground covers were present in the 1st group and absent in the 2nd group. This could be seen most dramatically in the distribution of the Theridion spp. and $M$. vitis. Theridion spp. made up $\approx 40 \%$ of the spiders collected at the RAISIN1, RAISIN2, and WINE3 sites, but $<8 \%$ at all other sites. RAISIN1, RAISIN2, and WINE3 lack summer ground covers (Table 1), suggesting that the distribution of Theridion spp. can be partly explained by the presence or absence of understory vegetation. Ground covers can contribute to a more continuous and diverse selection of prey for spiders (Mangan and Byers 1989), and this may have affected species composition in this study as well. Similarly, plant diversity has been linked to spider colonization (Bishop and Riechert 1990), and Theridion spp. may have a competitive advantage in colonization and establishment in vineyards without cover crops. $M$. vitis constituted $<1 \%$ of the spiders collected at RAISIN1, RAISIN2, and WINE3 but averaged $13 \%$ at all other sites and appears to be largely responsible for linking WINE2 and TABLE2,

Regressing seasonwide leafhopper density against total spider density resulted in a poor correlation (Table 4) and suggests that the total assemblage of spider species did not follow leafhoppers in a density-dependent manner. Regressing leafhopper density against individual spider species did, however, result in 2 significant relationships. Theridion spp. density was positively correlated to leafhopper density $(P=0.027)$, whereas $M$. vitis was negatively correlated $(P=0.030)$ (Table 4 ). The negative relationship between $M$. vitis and leafhoppers is interesting in that $M$. vitis will not feed on E. variabilis in the laboratory (unpublished data).

Seasonal Abundance. Abundance patterns of the 8 most common spider species pooled over all vineyards sampled in 1993 are shown by age class (Fig. 3). None of the life histories of any of these spiders has been fully documented in California; therefore, these abundance patterns provide some insight into their respective phenologies. Although juveniles made up $88 \%$ of all spiders collected, the only species that we were not able to distinguish from each other as juveniles were $O$. scalaris and $O$. salticus. The Oxyopes spp., $H$. nedra, and $T$. melanurum appear to have the most discrete life histories. Cutler et al. (1977) found that $O$. scalaris in Minnesota overwintered as juveniles, then matured in June. In California, Oxyopes spp. overwinter both as half-grown juveniles and as adults (unpublished data), which accounts for the high early-season adult density (Fig. 3A). By midseason (mean $=1,918$ DD 10, late June to early August), Oxyopes adults were rare. The steady increase in numbers of juveniles after the adult population had declined (Fig. 3A) may be explained by immigration, although the dispersal patterns of Oxyopes are not known. It may also be that larger instars of Oxyopes are more easily shaken out of the canopy, which increased the efficiency of our sampling method as the season progressed. $H$. nedra adults were collected during the first 2 sampling periods and, thereafter, only juveniles were found (Fig. 3B). Overwintered $H$. nedra adults lay egg clusters in the spring, with the main egg hatch period occurring between the first 2 sampling periods, resulting in peak juvenile density at mean $=$ 1,435 DD 10 (Fig. 3B); from this point, the population declined $30 \%$ by the end of the season, possibly as a result of competition for websites, predation, or other mortality factors. $H$. nedra matures in late September to early October (Carroll 1980). Collection of T. melanurum adults was also dependent on sampling period, with $92 \%$ of the specimens collected during spring and early-summer samples. Discreteness of generations is a major biological distinction between the 2 species of Theridion. T. melanurum produces all of its young early in the season (Fig. 3C), whereas T. dilutum 


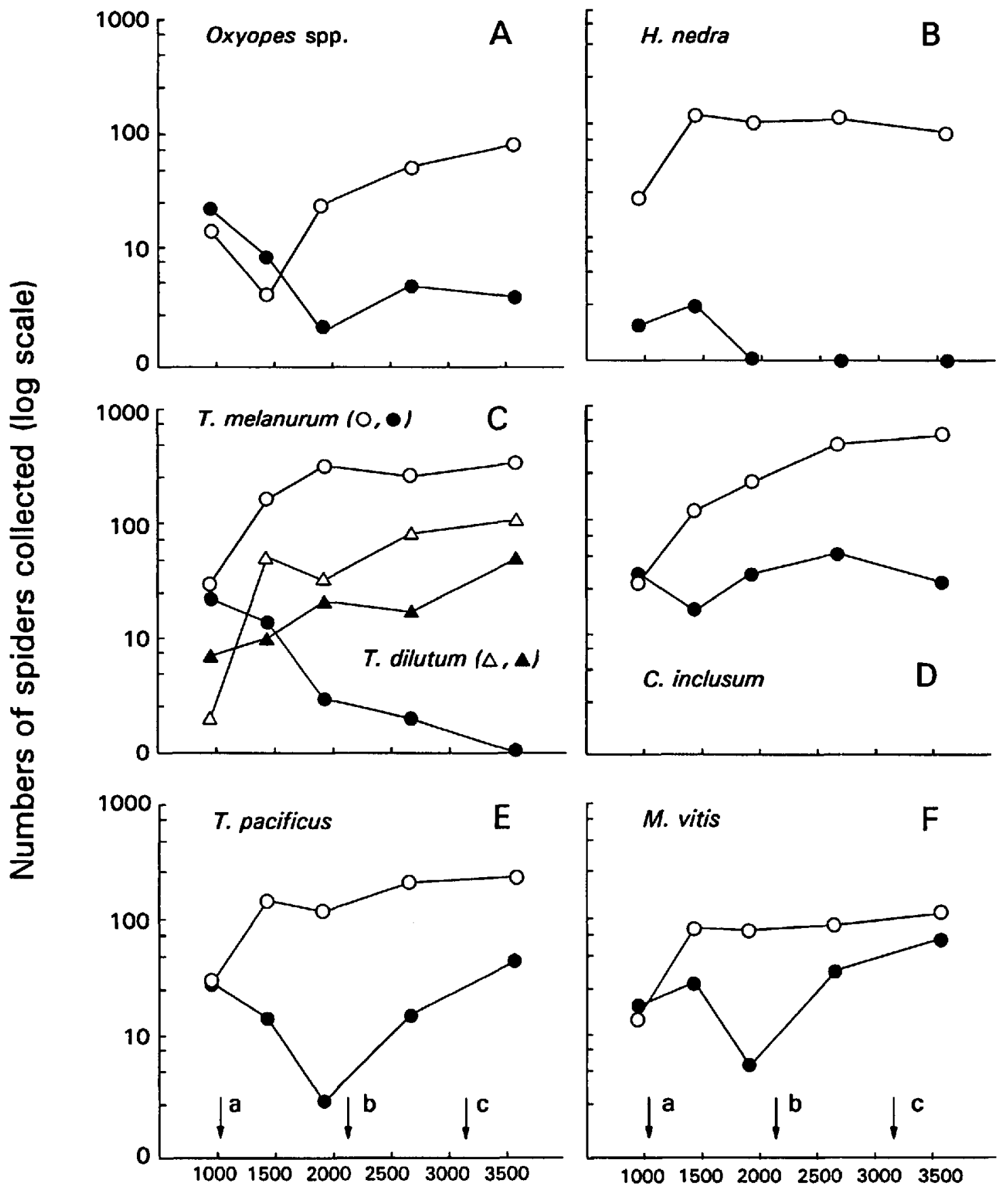

\section{Mean cumulative degree days $\left(D^{\circ} 10\right)$}

Fig. 3. Seasonal abundance of juveniles (o) and adults $(\bullet)$ of the 8 most commonly collected spider species. Numbers from all sites are pooled and plotted against mean cumulative degree-days $\left({ }^{\circ} \mathrm{C}\right)$ above a lower temperature threshold of $10^{\circ} \mathrm{C}$. Arrows indicate approximate periods in grape development for budbreak (a), veraison (b), and harvest $(c)$. 
partitions production of progeny, which may partly explain the greater overall abundance of $T$. melanurum over the course of the season (Fig. 3C). T. dilutum spiderlings, which hatch in mid-season, may be more vulnerable to predation or may disperse out of the vineyard because of fewer available web-building sites.

The remaining species appear to have overlapping age structure. Two distinct seasonal adult population peaks are seen for C. inclusum, T. pacificus, and $M$. vitis. These species overwinter as half-grown juveniles to adults (unpublished data), and therefore, adults collected in the lst sampling period are a combination of those which had overwintered as adults, as well as those which had overwintered as juveniles or subadults and matured in the spring. The number of $C$. inclusum adults was relatively high on the first sampling date, peaking again at midseason and declining thereafter (Fig. 3D), whereas populations of adult $T$. pacificus and $M$. vitis began high, declined at midseason, and increased thereafter (Fig. $3 \mathrm{E}$ and F). These lifehistory patterns may be explained partly by differences in numbers of egg sacs laid and adult longevity. Although Peck and Whitcomb (1970) found C. inclusum to be iteroparous, our observations are that the production of just 1 egg sac by $C$. inclusum is more common and that the female dies shortly after egg hatch. In the laboratory, if $C$. inclusum lays $>1$ egg sac, the latter are either infertile or of very low egg count (unpublished data). Therefore, it is probable that in nature $C$. inclusum is semelparous. In contrast, the other clubionid, $T$. pacificus, is iteroparous in the laboratory; females lay multiple egg cases over a period of many weeks and live longer than $C$. inclusum (unpublished data), which accounts for the linear increase in adult $T$. pacificus beginning at midseason. $T$. dilutum is also iteroparous. Numbers of adult $T$. dilutum sharply increased between mid-and late season (Fig. 3C). Of all the spider species, T. dilutum and $M$. vitis had the highest mid- to late season ratios of adults to juveniles. We have not observed the fecundity nor longevity of $M$. vitis.

\section{Acknowledgments}

We thank R. Mondavi Vineyards, H. Nadler, F. Smeds, and G. Swanson for use of their farms and J. Chevalier, $S$. Lange, and M. Shimozaki for their cooperation in management of the field sites. Field and laboratory assistance was provided by A. Bird, R. Craig, R. Greenwood, H. North, V. Quijano, C. Sisk, and Y. Rasmussen. Special thanks to $M$. Moody and C. Sisk for providing identifications of spider specimens and to R. Bugg and R. Breene for helpful comments on the manuseript. We gratefully acknowledge the financial support of the California Raisin Advisory Board, California Table Grape Commission, Lodi-Woodbridge Winegrape Commission, University of Califomia Statewide IPM Project, and the University of California Sustainable Agriculture Research and Education Project.

\section{References Cited}

Agnew, C. W. and J. W. Smith, Jr. 1989. Ecology of spiders (Araneae) in a peanut agroecosystem. Environ. Entomol. 18: 30-42

Anderson, J. F. 1970. Metabolic rates of spiders. Comp. Biochem. Physiol. 33: 51-72.

Bishop, A. L. 1980. The composition and abundance of the spider fauna in south-east Queensland cotton. Aust. J. Zool. 28: 699-708

Bishop, L. and S. E. Riechert. 1990. Spider colonization of agroecosystems: mode and source. Environ. Entomol. 19: 1738-1745

Breene, R. G., W. L. Sterling, and D. A. Dean. 1989. Predators of the cotton fleahopper on cotton. Southwest. Entomol. 14: 159-166.

Breene, R. G., D. A. Dean, M. Nyffeler, and G. B. Edwards. 1993. Biology, predation ecology and significance of spiders in Texas cotton ecosystems. Texas Agric. Exp. Stn. Bull. 1711.

Carroll, D. P. 1980. Biological notes on the spiders of some citrus groves in central and southern California. Entomol. News 91: 147-154.

Cate, J. R. 1975. Ecology of Erythroneura elegantula Osborn (Homoptera: Cicadellidae) in grape agroecosystems in California. Ph.D. dissertation, University of California, Berkeley.

Cutler, B., D. T. Jennings, and M. J. Moody. 1977. Biology and habitats of the lynx spider Oxyopes scalaris Hentz (Araneae: Oxyopidae). Entomol. News 88: 87-97.

Dean, D. A., W. L. Sterling, and N. V. Horner. 1982. Spiders in eastern Texas cotton fields. I. Arachnol. 10: 251-260.

Dondale, C. D., B. Parent, and D. Pitre. 1979. A 6year study of spiders (Araneae) in a Quebec apple orchard. Can. Entomol. 111: 377-380.

Ferguson, H. J., R. M. McPherson, and W. A. Allen. 1984. Ground- and foliage-dwelling spiders in four soybean cropping systems. Environ. Entomol. 13: 975-980.

Gertseh, W. 1979. American spiders. Van Nostrand Reinhold, New York.

Kirn, B. 1978. Untersuchung der epigaischen Spinnenfauna (Araneae) in Rebkulturen. Staatsexamensarbeit in Zoologie, University of Freiburg im Breisgau, Germany.

Knutson, A. E. and F. E. Gilstrap. 1989. Direct evaluation of natural enemies of the southwestern corn borer (Lepidoptera: Pyralidae) in Texas corn. Environ. Entomol. 18: 732-739.

Krebs, C. J. 1989. Ecological methodology. Harper Collins, New York.

LeSar, C. D. and J. D. Unzicker. 1978. Soybean spiders: species composition, population densities and vertical distribution. Ill. Nat. Hist. Surv. Biol. Notes 107.

Mangan, R. L. and R. A. Byers. 1989. Effects of minimum-tillage practices on spider activity in old-field swards. Environ. Entomol. 18: 945-952.

Mansour, F. and W. H. Whitcomb. 1986. The spiders of a citrus grove in Israel and their role as biocontrol agents of Ceroplastes floridensis (Homoptera; Coccidae). Entomophaga 31: 269-276.

MeDaniel, S. G. and W. L. Sterling. 1982. Predation of Heliothis virescens (F.) eggs on cotton in east Texas. Environ. Entomol. 11: 60-66. 
Nyffeler, M. and G. Benz. 1987. Spiders in natural pest control: a review. J. Appl. Entomol. 103: 321339.

Nyffeler, M., W. L. Sterling, and D. A. Dean. 1994. How spiders make a living. Environ. Entomol. 23: 1357-1367.

Peck, W. B. and W. H. Whitcomb. 1970. Studies on the biology of a spider, Chiracanthium inclusum (Hentz). Univ. Ark. Agric. Exp. Stn. Bull. 753.

Riechert, S. E. and T. Lockley. 1984. Spiders as biological control agents. Annu. Rev. Entomol. 29: 299320.

Rouch, S. J. 1980. Arthropod predators on cotton, corn, tobacco, and soybeans in South Carolina. J. Ga. Entomol. Soc. 15: 131-138.

Roltsch, W., R. Hanna, H. Shorey, M. Mayse, and F. Zalom. (1995). Spiders and vineyard habitat relationships in central California. In C. Pickett and R. Bugg [eds.], Enhancing natural control of arthropod pests through habitat management. AgAccess, Davis, CA.

SAS Institute. 1992. SAS user's guide: statistics, version 6.08 ed. SAS Institute, Cary, NC.

Settle, W. H., L. T. Wilson, D. L. Flaherty, and G. M. English-Loeb. 1986. The variegated leafhopper, an increasing pest of grapes. Calif. Agric. 40(7): 30-32.

Southwood, T.R.E. 1978. Ecological methods. Wiley, New York.

Wilson, L. T., M. M. Barnes, D. L. Flaherty, H. L. Andris, and G. M. Leavitt. 1992. Variegated grape leafhopper, pp. 202-213. In D. L. Flaherty, L. P. Christensen. W. T. Lanini, J. J. Marois, P. A. Phillips, and L. T. Wilson [eds.], Grape pest management. Univ. Calif. Div. Agric. Nat. Res. Publ. 3343.

Received for publication 2 November 1994; accepted 6 March 1995. 